\title{
DISHARMONI SISTEM INFORMASI AKUNTANSI PENERIMAAN DAN PIUTANG DENGAN PROSES BISNIS KEPABEANAN
}

\author{
Fauzi Ismail Arif \\ Universitas Airlangga \\ fauziismailarif@gmail.com \\ Debby Ratna Daniel \\ Universitas Airlangga \\ debby-r-d@feb.unair.ac.id
}

Received: $13-08-2017$

Revised: 11-10-2017

Accepted: $30-10-2017$

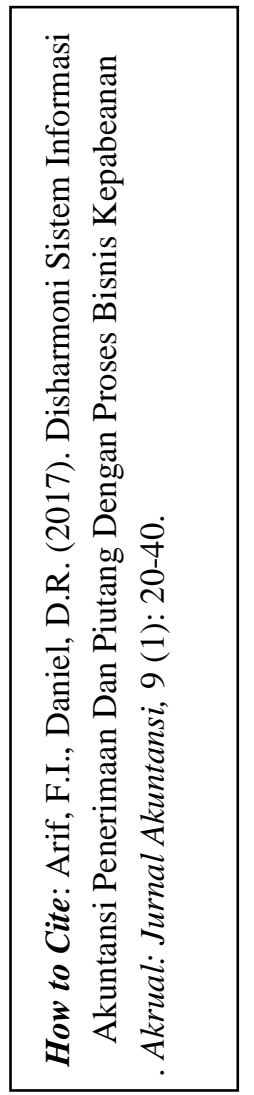

\section{ABSTRACT}

The purpose of this study is to explore the alignment of accounting information systems with business processes at the Directorate General of Customs and Excise to generate acceptance and profits that are reliable. The research method used qualitative method with explorative approach. Analytical technique using interview approach, observation, document, recording archive by looking from input control factor, process, and output. The result of the research shows that there is unconformity between accounting information system of receipt and receivable with customs business process. Applications run separately where systems built for different accounting and business processes are different. CEISA as a computerized service system, not connected to the reception system. Remove DJBC in addition to serving service users, also must consider the state revenue. In addition, the validation process of acceptance of the old General Accounting System makes it difficult for DJBC to believe in the delayed validity of acceptance in the Institution Accounting System. With regard to receivables, the entire contents of the document have not been through the Receivables and Refund System (SAPP). In addition, SAPP also can not be used directly as a statement of receivables.

Keywords: Customs, Reception, SAPP, Business Process

\section{ABSTRAK}

Tujuan penelitian ini adalah mengeksplor keselarasan sistem informasi akuntansi dengan proses bisnis di Direktorat Jenderal Bea dan Cukai untuk menghasilkan nilai penerimaan dan piutang yang handal. Metode penelitian menggunakan metode kualitatif dengan pendekatan eksploratif. Teknik analisis menggunakan pendekatan wawancara, observasi, dokumen, rekaman arsip dengan melihat dari aspek pengendalian input, proses, dan output. Hasil penelitian menunjukkan adanya ketidakselarasan antara sistem informasi akuntansi penerimaan dan piutang dengan proses bisnis kepabeanan. Keduanya berjalan terpisah dimana sistem yang dibangun untuk keperluan akuntansi dan proses bisnis berbeda. CEISA sebagai sistem komputerisasi pelayanan, tidak terhubung dengan sistem penerimaan. Padahal DJBC selain melayani pengguna jasa, juga harus mengamankan penerimaan negara. Selain itu, proses validasi penerimaan Sistem Akuntansi Umum yang lama mempersulit DJBC dalam meyakini validitas penerimaan yang tercatat dalam Sistem Akuntansi Instansi. Terkait piutang, seluruh penerbitan dokumen piutang belum melalui Sistem Aplikasi Piutang dan Pengembalian (SAPP). Selain itu, SAPP juga tidak dapat digunakan langsung sebagai laporan piutang.

Kata Kunci: Bea Cukai, Penerimaan, SAPP, Proses Bisnis, Kepabeanan 


\section{Pendahuluan}

Dalam rangka penyusunan laporan keuangan sesuai Sistem Akuntansi Pemerintah Pusat, nilai penerimaan DJBC yang dicatat berdasarkan SAI harus direkonsiliasi dengan catatan penerimaan Sistem Akuntansi Umum (SAU). Pencatatan menurut SAU dilakukan oleh Bendahara Umum Negara (BUN). Berdasarkan hasil pemeriksaan Badan Pemeriksa Keuangan Republik Indonesia (BPK RI) di DJBC, sejak tahun 2013 sampai dengan tahun 2015 masih ditemukan kelemahan pengendalian intern pada penerimaan perpajakan. Beberapa diantaranya adalah:

a. Penerimaan perpajakan Sistem Akuntansi Instansi (SAI) tidak dapat direkonsiliasi dengan penerimaan menurut Sistem Akuntansi Umum (SAU) atau disebut SAI unmatch

b. Data penerimaan SAU tidak dapat ditelusuri atau disebut SAU unmatch

c. Metode rekonsiliasi penerimaan belum optimal

Implikasi SAI unmatch adalah adanya transaksi penerimaan yang diakui DJBC, tetapi tidak diakui BUN. Dengan kata lain, DJBC harus dapat membuktikan data penerimaan tersebut melalui dokumen sumber. Apabila DJBC tidak dapat menunjukkan dokumen sumbernya, maka asersi keberadaan penerimaan tersebut dapat dipertanyakan. Hal ini sangat berisiko karena dalam proses bisnis DJBC, mayoritas kewajiban perpajakan dibayar pada saat melakukan kegiatan kepabeanan.

Sebaliknya, implikasi dari SAU unmatch adalah adanya transaksi penerimaan yang diakui BUN, tetapi tidak diakui atau belum dicatat DJBC. Hal ini dapat mengakibatkan penerimaan DJBC dinyatakan understated. Apabila penerimaan tersebut merupakan pembayaran pelunasan piutang, maka piutang outstanding DJBC juga dapat dinyatakan overstated.

Selama tahun 2012-2015, selisih pencatatan penerimaan menurut SAI dan SAU semakin membesar (lihat tabel 1.1). Pada tahun 2015, selisih pencatatan mengalami kenaikan sampai sembilan kali lipat dibanding selisih pada tahun 2012. Bahkan selisih nilai penerimaan tersebut bukanlah selisih nilai absolut.

Tabel 1

Penerimaan Perpajakan DJBC (Bruto) Tahun 2012-2015

\begin{tabular}{cccr}
\hline Tahun & SAI $(\mathbf{R p})$ & SAU $(\mathbf{R p )}$ & \multicolumn{1}{c}{ Selisih $(\mathbf{R p )}$} \\
\hline 2012 & 145.242 .043 .037 .038 & 145.283 .354 .490 .808 & 41.311 .453 .770 \\
2013 & 156.435 .387 .177 .777 & 156.485 .040 .753 .738 & 49.653 .575 .961 \\
2014 & 162.201 .604 .730 .010 & 162.314 .718 .848 .754 & 113.114 .118 .744 \\
2015 & 180.125 .841 .028 .258 & 180.489 .306 .561 .586 & 363.465 .533 .328 \\
\hline
\end{tabular}

Sumber: Laporan Keuangan Kementerian Keuangan Tahun 2012-2015

Realisasi penerimaan perpajakan

DJBC juga disokong dari pelunasan piutang.

Selama tahun 2015, DJBC menerbitkan dokumen sumber piutang senilai Rp169,3 triliun. Selanjutnya di tahun yang sama, terdapat mutasi kurang piutang sebesar Rp189,2 triliun. Koreksi saldo awal yang dilakukan tiap tahun cukup tinggi terutama 
AKRUAL: Jurnal Akuntansi, volume 9, nomor 1, Oktober 2017, (20-40)

tahun 2015. Koreksi saldo dilakukan internal

audited tahun sebelumnya. (lihat tabel 1.3).

DJBC atas nilai piutang pada laporan keuangan

Tabel 2

Mutasi Piutang Perpajakan DJBC Tahun 2012-2015 (dalam Rupiah)

\begin{tabular}{ccccc}
\hline Tahun & Saldo Awal & \multicolumn{1}{c}{ Koreksi Saldo } & Mutasi Tambah & Mutasi Kurang \\
\hline 2012 & 21.262 .095 .927 .301 & -52.951 .321 .046 & 105.358 .812 .339 .807 & 103.820 .612 .489 .522 \\
2013 & 22.747 .344 .456 .536 & 72.957 .502 .155 & 129.690 .234 .500 .113 & 126.636 .848 .774 .044 \\
2014 & 25.873 .687 .684 .761 & -53.749 .717 .070 & 161.088 .972 .441 .933 & 162.885 .458 .930 .338 \\
2015 & 24.023 .451 .479 .286 & 375.526 .785 .102 & 169.280 .858 .376 .251 & 189.231 .115 .014 .822 \\
\hline
\end{tabular}

Sumber: Laporan Keuangan DJBC Tahun 2012-2015

Beberapa penyebab ketidaktepatan pencatatan nilai piutang tersebut diantaranya dokumen piutang awal belum dicatat (understated) dan piutang outstanding yang ternyata sudah dilunasi (overstated). Implikasi dari understated piutang adalah risiko adanya hak negara yang hilang atas tidak tercatat dan tertagihnya piutang tersebut. Di sisi lain, overstated piutang dapat mengganggu kelancaran pengusaha pabean karena akan dilakukan pemblokiran kegiatan kepabeanan oleh DJBC. Selain itu, overstated piutang juga mengakibatkan ketidaktepatan pelaksanaan tugas DJBC dalam optimalisasi penerimaan dari penagihan piutang. Dikhawatirkan, informasi yang tidak relevan dan cukup tidak dapat digunakan sebagai bahan pengambilan keputusan (Ramli dan Iskandar, 2014). Padahal informasi merupakan sumber daya yang penting untuk mengelola organisasi yang modern (Ada dan Ghaffarzadeh, 2015; Elliott, 1992).

Kesalahan akuntansi pendapatan dan piutang salah satunya disebabkan kelemahan pengendalian internal atas teknologi informasi (Grant dkk., 2008). Ditegaskan pula oleh Burks (2015), letak kesalahan teratas pada organisasi non profit adalah pendapatan dan piutang.
Beberapa penyebab masalah sistem informasi diantaranya yaitu kesalahan perhitungan manual, pertukaran dokumen, kelemahan, dan ketidakcukupan pengendalian internal (Bell dkk., 1998). Padahal teknologi informasi dapat memperlancar proses bisnis, menghasilkan informasi yang dapat dipercaya, relevan, tepat waktu, lengkap, dapat dipahami, dan teruji (Maharsi, 2000). Jaringan teknologi informasi juga mempersingkat waktu yang dibutuhkan oleh akuntan untuk menyiapkan dan menyajikan informasi keuangan kepada manajemen (Ghasemi dkk., 2011).

Sistem informasi akuntansi sangat penting bagi entitas bisnis karena dapat meningkatkan kecepatan, akurasi (Abdallah dan Adel, 2013; Lim, 2013; Moorthy dkk., 2012), dan mendukung pelaporan keuangan secara realtime dan rinci (O'Donnell dan David, 2000). Dengan demikian, sistem informasi akuntansi harus memperhatikan kepentingan pengguna informasi (FlorinConstantin, 2013; Gheorghe, 2012).

Berbagai aplikasi sistem informasi dengan berbagai platform teknologi dan perangkat teknologi informasi pendukungnya berdampak pada mahalnya pemeliharaan, tidak efektif, susah dikembangkan, dan sulit integrasi dengan sistem lain (Bisbal dkk., 
Arif,Daniel, Disharmoni Sistem Informasi Akuntansi Penerimaan Dan Piutang...

1999). Kondisi tersebut membuat sistem informasi tidak dapat menyediakan dan mengolah informasi secara efektif bagi unit organisasi. (Surendro, 2007). Ketidaksinkronan proses bisnis dengan sistem informasi dapat menyebabkan risiko kehilangan penerimaan, pelanggaran, dan mengganggu pelaksanaan tugas (Huang dkk., 2009). Padahal sulit untuk mengintegrasikan secara sistemik akuntansi, sistem informasi akuntansi, dan hubungannya dengan proses bisnis (Patasiene dkk., 2015; Sonnenberg dan Jan vom, 2014).

Kebutuhan atas akuntabilitas membuat evaluasi sistem informasi lebih komplek dibanding sektor privat. Oleh karena itu dibutuhkan pengendalian sistem informasi untuk menjamin validitas, reliabilitas, dan keamanan informasi (Newcomer dan Caudle, 1991). Rumitnya, meskipun pengendalian ditingkatkan, sistem informasi yang bertambah kompleks menyebabkan peningkatan kerentanan sistem informasi pula (Cong dan Romero, 2013)

Hanya sedikit penelitian yang menghubungkan akuntansi dan teknologi informasi dari aspek manajerial dan pengendalian (Granlund, 2011). Padahal pengendalian yang tidak tersinkronisasi dengan proses bisnis dapat memperlama proses dan memperpanjang birokrasi (Cram dan Gallupe, 2016). Di sisi lain, ketentuan laporan keuangan yang memenuhi kebutuhan informasi para pembayar pajak perlu mendapat perhatian (PP 71 Tahun 2010). Berdasarkan uraian tersebut, penelitian mengenai harmonisasi sistem informasi akuntansi penerimaan dan piutang perpajakan dengan proses bisnis di DJBC penting untuk dilakukan.

\section{TINJAUAN TEORITIS}

\section{Teori Sistem Umum}

Terdapat kompleksitas pola interaksi antara sub-sub sistem (unit). Pemahaman tentang subsub sistem atau komponen sistem dan interaksi yang terjadi akan dapat membantu memahami keseluruhan sistem (Von Bertalanffy, 1972). Teori sistem umum digunakan untuk menganalisis sub sistem penerimaan dan piutang, serta interaksi antar sub-sub sistem didalamnya. Pola interaksi tersebut dilihat mulai dari penerimaan, pemrosesan, sampai dengan pelaporan, dengan melihat kesesuaian sumber data dan sistem lain yang mempengaruhi. Selain itu didalami bagaimana data penerimaan dan data piutang terkoneksi, koreksi yang dilakukan, hal-hal yang menyebabkan data seharusnya berubah, rekonsiliasi dengan data pembanding, dan bagaimana sistem tersebut bersinggungan dengan sistem informasi lain yang ada di DJBC.

\section{Teori Keselarasan}

Teori keselarasan menjelaskan bagaimana teknologi informasi dapat selaras dengan bisnis, dan bagaimana bisnis harus atau bisa selaras dengan teknologi informasi juga (Luftman dan Brier, 1999). Keselarasan berarti aktivitas manajemen untuk mencapai suatu tujuan antara teknologi informasi dan fungsional organisasi, misalnya keuangan. Keselarasan bisnis dan teknologi informasi juga terkait dengan jumlah aplikasi teknologi informasi yang digunakan, infrastruktur dan 
AKRUAL: Jurnal Akuntansi, volume 9, nomor 1, Oktober 2017, (20-40)

organisasi, strategi dan proses bisnis untuk mewujudkannya (Silvius, 2007).

Berdasarkan teori keselarasan, antara sistem informasi akuntansi harus selaras dengan proses bisnis yang dijalankan. Keduanya harus saling melengkapi dan bukan berjalan secara terpisah. Pemrosesan data untuk tujuan pelaporan keuangan dan tujuan proses bisnis selayaknya terintegrasi dan data yang digunakan adalah data yang sama.

Pola pemikiran teori keselarasan ketika diaplikasikan di DJBC, sangat sesuai untuk mengharmonisasikan adanya suatu alur yang terpisah antara sistem informasi akuntansi dengan proses bisnis yang berjalan. Sebagai contoh bentuk keselarasan diantaranya penerbitan surat penetapan piutang, monitoring penyelesaian, sampai dengan mutasi kurang seharusnya melalui suatu sistem terkomputerisasi yang terintegrasi. Dengan demikian, angka piutang yang dihasilkan pun bergerak sejalan dengan proses bisnis tindakan kepabeanan.

Terkait dengan penerimaan, pola pemikiran dari teori keselarasan tidak jauh berbeda dengan penerapan di piutang. Integrasi data penerimaan dengan proses bisnis pelayanan kepabeanan secara terkomputerisasi diperlukan sebagai bentuk harmonisasi sistem informasi akuntansi dengan proses bisnis. Disamping itu, ketersediaan data penerimaan dari SAU tetap dibutuhkan secara periodik sebagai pembanding data penerimaan yang tercatat dalam sistem DJBC. Konsekuensinya, ketika ada koreksi juga dilakukan di dalam sistem dan tercatat perubahannya untuk keperluan audit trail. Dengan demikian, pelaporan penerimaan menjadi satu kesatuan utuh yang diproses sistem.

\section{Sistem Informasi Akuntansi}

Sistem informasi akuntansi merupakan subsistem dari sistem informasi manajemen karena terkait dengan penyediaan informasi yang terintegrasi untuk membantu pengambilan keputusan bagi berbagai tingkatan manajemen dalam suatu organisasi (IoanaDiana, 2013).

Sistem informasi akuntansi diharapkan dapat memenuhi tiga fungsi penting dalam organisasi (Romney dan Steinbart, 2015), yaitu:

a. Mengumpulkan dan menyimpan data;

b. Mengubah data menjadi informasi;

c. Menyediakan pengendalian yang memadai untuk menjaga aset dan data organisasi, agar tersedia saat dibutuhkan, akurat, dan andal.

Ketika sistem informasi akuntansi sudah berjalan dengan baik, akan mudah bagi DJBC untuk merencanakan, mengendalikan, dan mengevaluasi lebih tepat.

Terdapat desain sistem yang berbedabeda dengan mempertimbangkan faktor-faktor yang mempengaruhi pengumpulan dan pelaporan informasi. Desain sistem juga dapat tergantung pada ukuran perusahaan, volume data transaksi, sifat operasi, struktur organisasi, dan bentuk usaha (Lim, 2013). 


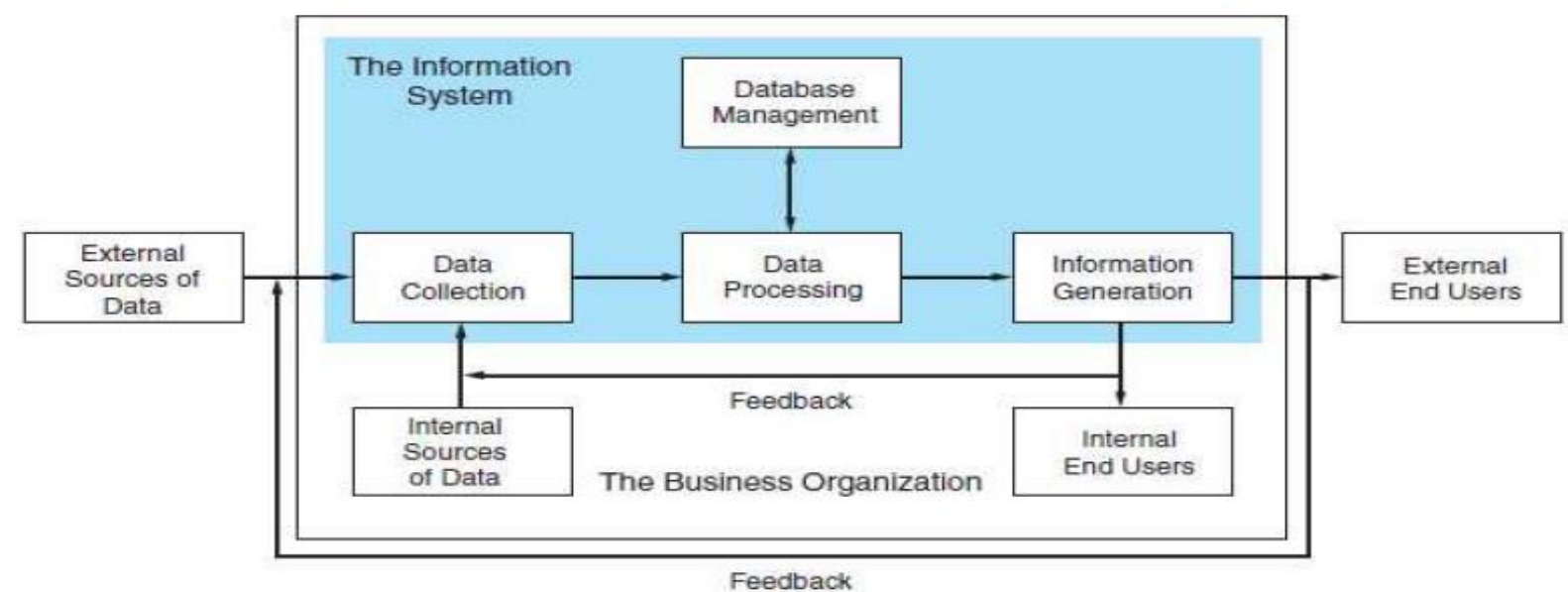

Gambar 1. Alur Sistem Informasi Akuntansi

Tahap operasional pertama sistem informasi akuntansi (Gambar 2.1), adalah pengumpulan data. Tujuannya memastikan bahwa masuknya data valid, lengkap dan bebas dari kesalahan material. Tahap ini mementingkan relevansi dan efisiensi dimana sistem hanya menangkap data yang relevan dan mengumpulkan data sekali saja. Sumber data dapat diperoleh dari internal atau eksternal. Setelah data dikumpulkan, lalu akan disimpan dalam pengelolaan database dan akan diolah menjadi informasi. Proses yang berhubungan dengan pengolahan data bervariasi dari yang sederhana sampai yang kompleks dan meringkas prosedur akuntansi. Informasi yang dihasilkan kemudian akan diteruskan ke pengguna akhir eksternal dan pengguna akhir internal. Selanjutnya masukan dari pengguna dikirim kembali ke entitas sebagai umpan balik (Lim, 2013).

\section{Metode Penelitian}

Penelitian ini menggunakan metode kualitatif dengan pertimbangan untuk mendapatkan gambaran utuh proses sistem informasi akuntansi penerimaan dan piutang perpajakan DJBC yang sebenarnya dan merangkai kembali sistem informasi tersebut agar selaras dengan proses bisnis. Hal ini sesuai dengan Sugiyono (2016) dimana untuk mendapatkan data yang mendalam, sebenarnya, dan pasti digunakan metode kualitatif.

Selanjutnya pendekatan penelitian menggunakan studi kasus dengan pertimbangan dapat menjawab pertanyaan 'bagaimana' pada pertanyaan penelitian yang diarahkan pada rangkaian peristiwa kontemporer, dimana peneliti tidak dapat melakukan kontrol terhadap peristiwa tersebut (Yin, 1996).

Penelitian dilakukan di Surabaya dan Jakarta sesuai dengan lokasi target informan. Tempat penelitian dilakukan di Kantor Pusat DJPB, Sekretariat Jenderal, Kantor Pusat DJBC, KPU DJBC, dan KPPBC sesuai objek penelitian. Penelitian dilaksanakan pada bulan Februari sampai dengan Juni 2017.

Sasaran penelitian ini adalah sistem informasi akuntansi penerimaan dan piutang perpajakan DJBC dan proses bisnis 
AKRUAL: Jurnal Akuntansi, volume 9, nomor 1, Oktober 2017, (20-40)

pendukungnya. Guna mengetahui lebih detail mengenai obyek penelitian tersebut, digunakan purposive sampling untuk memperoleh subyek penelitian. Pihakpihak yang dapat memberikan informasi diperoleh dari dokumen Organisasi dan Tata Laksana Kementerian Keuangan (2015) beserta peraturan turunannya. Selanjutnya dilakukan pengecekan pada dokumen Standard Operational Procedure (SOP) untuk menentukan unit yang terkait dengan penelitian. Apabila tidak ditemukan dalam SOP, maka akan dilakukan konfirmasi secara langsung pada saat penelitian dilakukan.

a. Direktorat Penerimaan dan Perencanaan Strategis, DJBC

b. Bagian Keuangan, Sekretariat DJBC

c. Kantor Pelayanan Utama BC Tipe A Tanjung Priok

d. KPPBC Madya Pabean Tanjung Perak

e. Bagian Akuntansi dan Pelaporan Keuangan, Sekretariat Jenderal

f. Direktorat Sistem Informasi dan Teknologi Perbendaharaan, DJPB

Data primer diperoleh dari wawancara semi terstruktur dan observasi partisipan moderat pada unit perbendaharaan dan keuangan DJBC. Data sekunder berupa dokumen dan rekaman arsip, diantaranya Perdirjen Penatausahaan Penerimaan, Piutang, dan Rekonsiliasi Penerimaan, laporan periodik, database penerimaan dan piutang, dan SOP. Bukti penelitian yang terkumpul dikelompokkan dan dilakukan reduksi data dengan memilih hal yang pokok dan polanya, sehingga data dapat memberikan gambaran yang lebih jelas (Sugiyono, 2016). Pengorganisasian data dilakukan dengan membagi berdasarkan empat peran dalam alur sistem informasi, yaitu: penatausahaan piutang, penatausahaan penerimaan, pelaporan keuangan, dan penyedia data pembanding.. Selanjutnya analisis data dilakukan melalui ketiga tahapan analisis, yaitu: (1) Identifikasi sistem dan proses bisnis penerimaan dan piutang, (2) identifikasi permasalahan sistem dan proses bisnis yang mempengaruhi input, proses, dan output data penerimaan dan piutang kepabeanan, dan (3) analisis pengendalian input, proses, dan output.

\section{ANALISIS DATA DAN PEMBAHASAN}

\section{Pengendalian Input Penerimaan}

Pengendalian input penerimaan dititikberatkan pada kelengkapan data dan koreksi akun di DJBC. Hal ini sesuai dengan hasil penelitian dimana SAU unmatch terjadi akibat ketidaklengkapan data penerimaan.

\section{Kondisi Saat Ini}

Aliran data penerimaan mulai dari Setelmen MPN G2 sampai CEISA dijelaskan pada Gambar 4.X. Data pembayaran dari Setelmen MPN G2 dikirimkan melalui sistem billing DJBC Pusat. Selanjutnya sistem billing DJBC meneruskan kembali kepada billing kantor pelayanan yang secara otomatis memadankan data dengan PIB di CEISA. Apabila data pembayaran billing ada padanannya dengan PIB, maka akan muncul status rekon di CEISA. 
Arif,Daniel, Disharmoni Sistem Informasi Akuntansi Penerimaan Dan Piutang...

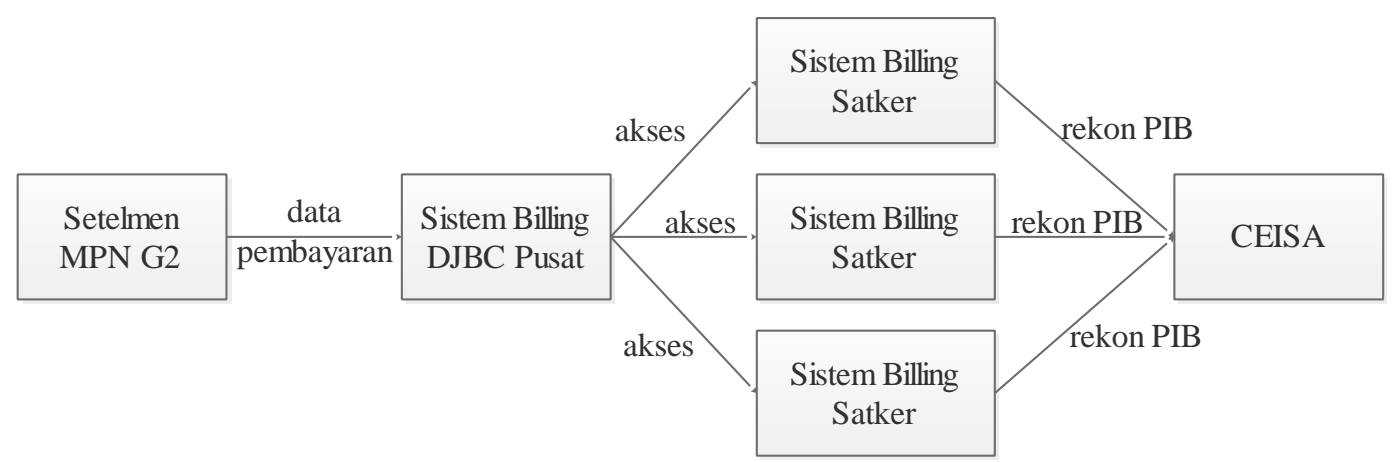

Gambar 2. Alur Data Setelmen Sampai CEISA

Adanya jeda waktu (time lag) antara pembayaran yang dilakukan oleh importir yang tercantum dalam setelmen MPN G2 sampai dengan data pembayaran diterima oleh sistem billing membuat pelayanan agak terganggu. Jeda waktu rata-rata enam jam tersebut membuat importir tidak bisa melakukan kegiatan kepabeanan seketika pada saat pembayaran telah dilakukan. Dengan demikian, sistem penerimaan yang masih belum dapat terhubung langsung seperti halnya perbankan mengganggu kecepatan proses kegiatan kepabeanan.

Sistem database antara biling DJBC pusat dengan tingkat satker berbeda. Pemisahan database billing antara pusat dengan satker membuat adanya data ganda. Alasan adanya pemisahan ini adalah kekhawatiran ketidakmampuan server yang digunakan langsung untuk pelayanan nasional, sehingga harus dipisahkan. Guna keperluan rekonsiliasi penerimaan, masing-masing satker akan mengunduh database billing sesuai dengan akses yang diberikan.
Permasalahannya, data penerimaan yang diunduh dari data billing tingkat KPPBC dan KPU (satuan kerja) ada yang tidak lengkap. Jumlah data yang diunduh tidak sama atau lebih sedikit dibandingkan jumlah data pada database billing pusat. Data yang diunduh dari billing satker dimasukkan ke dalam kertas kerja penerimaan, padahal data tersebut tidak lengkap. Hal ini mengakibatkan understated penerimaan DJBC, dimana nilai penerimaan yang dilaporkan lebih rendah dibanding nilai penerimaan sesungguhnya. Nilai inilah yang nantinya dapat menjadi SAU unmatch.

Proses pengisian kertas kerja penerimaan tidak hanya mengandalkan data unduhan dari sistem billing. Data billing merupakan data awal pembayaran. Apabila terjadi koreksi data pembayaran yang diajukan oleh importir, maka kantor pelayanan akan melakukan koreksi di aplikasi billing dan mengajukan permohonan koreksi kepada KPPN (Gambar 2). Data koreksi inilah yang biasanya lupa digunakan pada saat mengisi kertas kerja penerimaan. 


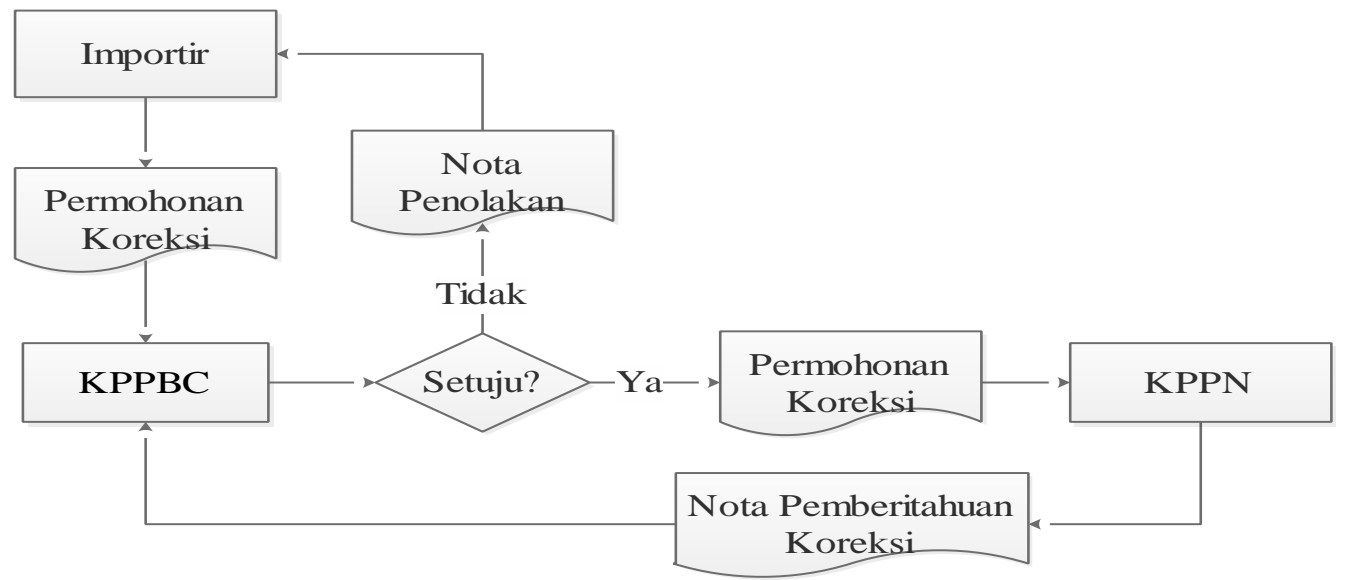

Gambar 3. Proses Koreksi Penerimaan

Mekanisme koreksi yang belum
tersistem dapat menyebabkan adanya
kesalahan input dalam data penerimaan. Terdapat celah kesalahan jika data penerimaan telah diunduh harian dan koreksi dilakukan pada hari berikutnya. Dengan demikian, apabila operator atau penatausaha penerimaan tidak melakukan reviu atas koreksi yang dilakukan, maka data penerimaan harian tersebut sudah tidak valid.

Mekanisme pengendalian yang ideal berdasarkan teori keselarasan adalah menjadikan proses akuntansi selaras dengan proses bisnis yang ada. Sehingga menjadi satu kesatuan utuh, bukan menjadi dua hal yang berbeda. Sistem informasi akuntansi juga mendukung proses bisnis. Dengan demikian, harus ada kesatuan database yang digunakan baik untuk akuntansi maupun untuk pelayanan. Pemisahan database dengan alasan ketidakmampuan server adalah suatu hal yang kurang realistis mengingat perkembangan teknologi yang sedemikian rupa, mengingat jenis dan jumlah transaksi yang masih terbilang jauh lebih rendah dibandingkan kerumitan transaksi perbankan.Database tunggal sudah selayaknya digunakan untuk proses bisnis agar segala laporan dan pengendalian lebih valid.

Terkait dengan adanya koreksi atas data pembayaran yang telah dilakukan, mekanismenya tetap melalui sistem. Sehingga tidak terjadi adanya penginputan ganda (redundancy). Koreksi yang dilakukan secara sistem juga dapat mendorong CEISA sebagai sumber data penerimaan, tidak hanya sebagai aplikasi pelayanan. Nota pemberitahuan koreksi yang masih memerlukan surat manual dari KPPN dilakukan perekaman ke CEISA Impor sebagai notifikasi bahwa koreksi yang diajukan telah dibukukan di pembukuan SAU.

Mekanisme koreksi yang belum tersistem dapat menyebabkan adanya kesalahan input dalam data penerimaan. Terdapat celah kesalahan jika data penerimaan telah diunduh harian dan koreksi dilakukan pada hari berikutnya. Dengan demikian, apabila operator atau penatausaha penerimaan tidak melakukan reviu atas koreksi yang dilakukan, maka data penerimaan harian tersebut sudah tidak valid. 


\section{Pengendalian Ideal}

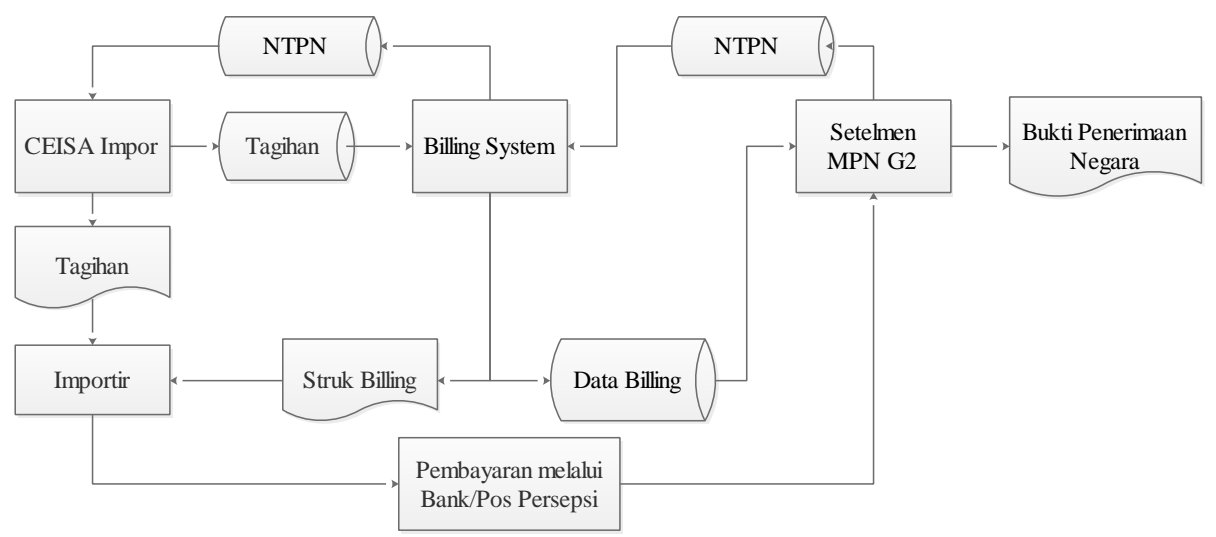

Gambar 4. Database Terpusat

Mekanisme pengendalian yang ideal

berdasarkan teori keselarasan adalah menjadikan proses akuntansi selaras dengan proses bisnis yang ada. Sehingga menjadi satu kesatuan utuh, bukan menjadi dua hal yang berbeda. Sistem informasi akuntansi juga mendukung proses bisnis. Dengan demikian, harus ada kesatuan database yang digunakan baik untuk akuntansi maupun untuk pelayanan. Pemisahan database dengan alasan ketidakmampuan server adalah suatu hal yang kurang realistis mengingat perkembangan teknologi yang sedemikian rupa, mengingat jenis dan jumlah transaksi yang masih terbilang jauh lebih rendah dibandingkan kerumitan transaksi perbankan.Database tunggal sudah selayaknya digunakan untuk proses bisnis agar segala laporan dan pengendalian lebih valid.

Terkait dengan adanya koreksi atas data pembayaran yang telah dilakukan, mekanismenya tetap melalui sistem. Sehingga tidak terjadi adanya penginputan ganda (redundancy). Koreksi yang dilakukan secara sistem juga dapat mendorong CEISA sebagai sumber data penerimaan, tidak hanya sebagai aplikasi pelayanan. Nota pemberitahuan koreksi yang masih memerlukan surat manual dari KPPN dilakukan perekaman ke CEISA Impor sebagai notifikasi bahwa koreksi yang diajukan telah dibukukan di pembukuan SAU.

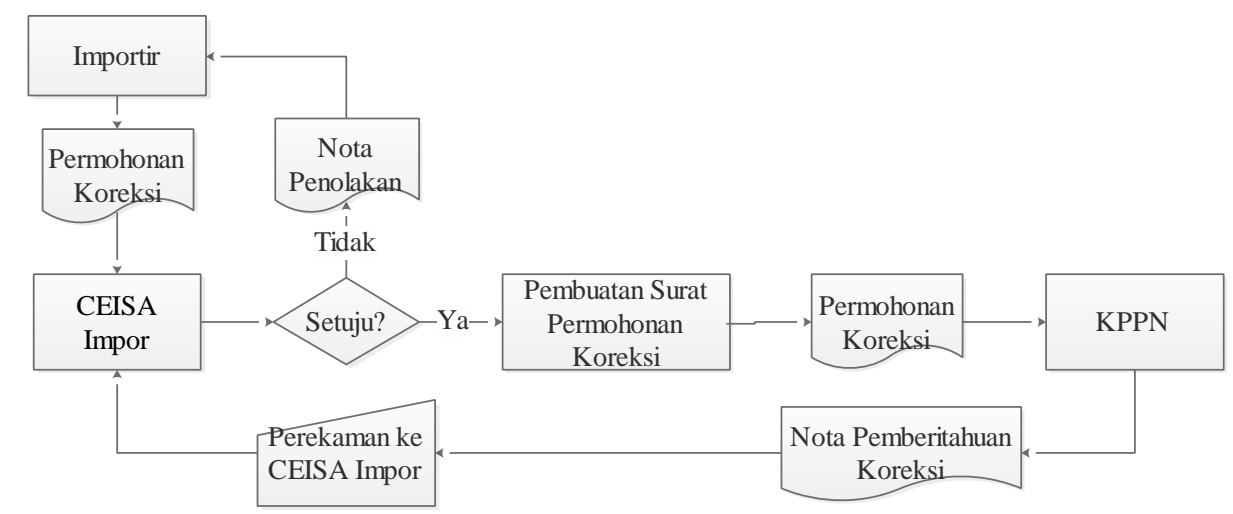

Gambar 5. Koreksi Data Pembayaran 
AKRUAL: Jurnal Akuntansi, volume 9, nomor 1, Oktober 2017, (20-40)

\section{Pengendalian Antara}

Sebagai langkah jangka pendek sebelum pemusatan database, DJBC dapat menggunakan data unduhan dari database sistem billing pusat. Data pusat digunakan sebagai pembanding untuk mengetahui kelengkapan data tingkat satker. Hal ini diperlukan untuk menguji kembali validitas aplikasi billing dan pengisian kertas kerja penerimaan di tingkat satker.

Selanjutnya terkait koreksi, data billing merupakan data penerimaan awal. Apabila pada suatu periode dilakukan koreksi atas akun atau kode kantor yang diajukan kantor pelayanan DJBC ke KPPN, data koreksi tersebut harus disandingkan pula dengan data billing (Gambar 5). Pada tingkat pusat, DJBC dapat meminta koreksi data secara total yang diajukan oleh DJBC kepada DJPB. Dengan demikian, pada tingkat pusat juga memiliki data pembanding untuk menguji kebenaran data penerimaan satker.

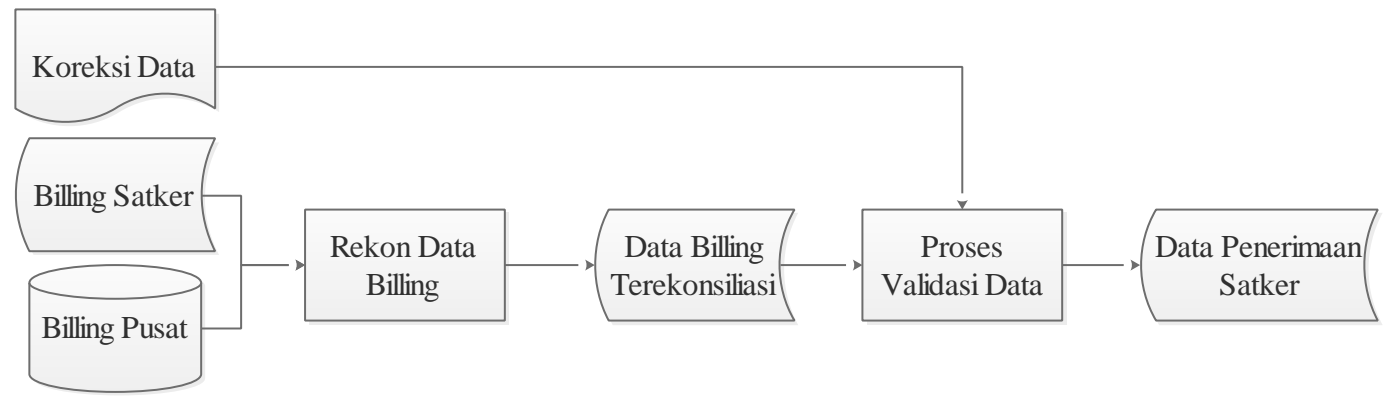

Gambar 6. Pengendalian Input Penerimaan

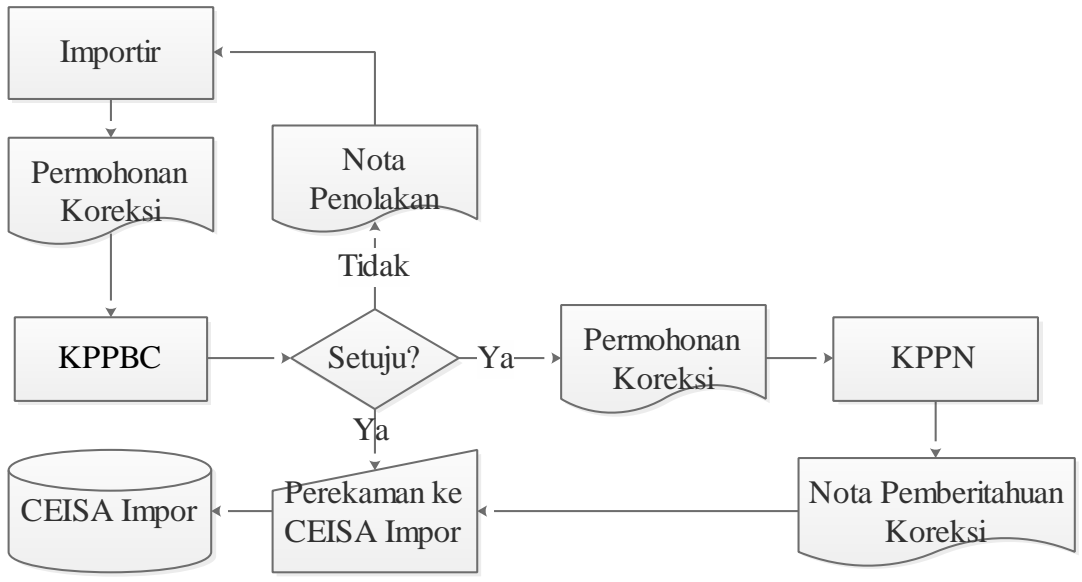

Gambar 7. Data Koreksi Masuk CEISA

\section{Pengendalian Proses Penerimaan}

\section{Kondisi Saat Ini}

Penggunaan MPN G2 secara penuh mulai tahun 2017 membuat seluruh penerimaan DJBC dilakukan melalui sistem billing. Dengan demikian, data sumber yang digunakan sepenuhnya berasal dari aplikasi billing. Pengendalian proses atas data penerimaan dilakukan dengan mengunduh dari aplikasi billing satker yang selanjutnya dilakukan pencocokan data batch antara hasil unduhan dengan aplikasi billing. Setelah data sesuai, maka dilakukan pengisian kertas kerja penerimaan.

Guna menjaga agar nilai yang dihasilkan sesuai, maka pada saat rekonsiliasi 
Arif,Daniel, Disharmoni Sistem Informasi Akuntansi Penerimaan Dan Piutang...

penerimaan dan penyusunan laporan keuangan dibuatkan berita acara rekonsiliasi. Seksi perbendaharaan membuat Berita Acara Rekonsiliasi (BAR) penerimaan dan piutang untuk disampaikan kepada seksi keuangan sebagai penyusun laporan keuangan. Namun pada tahap penyusunan laporan keuangan tingkat eselon I, belum dibuat BAR yang seharusnya disusun oleh Direktorat PPS kepada Bagian Keuangan DJBC.

\section{Pengendalian Ideal}

Pengendalian proses penerimaan yang ideal semestinya dengan menjaga jumlah batch di SAU dengan batch penerimaan di sistem CEISA sesuai. Karena data dari MPN ke SAU perlu waktu yang relatif lama, data penerimaan di CEISA dapat dibagi berdasarkan flag, misalkan flag "rekon SAU", "rekon SPAN", atau "rekon MPN" Kode billing digunakan sebagai elemen kunci karena kode tersebut tidak berubah sejak dari MPN sampai dengan SAU. Dengan demikian, secara proses, transaksi penerimaan tersebut terpantau. Pada tiap periode, dilakukan konfirmasi antara DJBC dengan DJPB untuk memastikan jumlah batch penerimaan telah sesuai.

\section{Pengendalian Antara}

Sebelum data SAU dan data SAI terkoneksi secara sistem di CEISA, DJBC dapat melakukan pengendalian proses melalui pengecekan secara rutin dengan meminta tabel validasi SAU melalui pertukaran data. Tabel validasi SAU yang dibuat oleh DJPB dimutakhirkan setiap hari. Dengan demikian,
DJBC dapat mengunduh data validasi SAU untuk dapat dibandingkan dengan penerimaan SAI. Hasil dari pembandingan secara batch ini dapat digunakan sebagai evaluasi validitas data penerimaan DJBC.

\section{Pengendalian Output Penerimaan}

\section{Kondisi Saat Ini}

Rekonsiliasi penerimaan atas Laporan Keuangan DJBC Tahun Anggaran 2016 dilakukan dengan membandingkan data penerimaan DJBC yang diperoleh dari data billing dengan data penerimaan SAU DJPB. Rekonsiliasi antara SAI dengan SAU dilakukan dengan menggunakan delapan level berdasarkan elemen kunci. Elemen kunci dalam setiap level tersebut digunakan untuk menghindari adanya hasil rekon ganda. Kedelapan urutan level rekonsiliasi yaitu:

a. Metode-1 dengan elemen kunci NTPN. TGL. NTPN. AKUN. NILAI;

b. Metode-2 dengan elemen kunci NTPN. AKUN. NILAI;

c. Metode-3 dengan elemen kunci NTPN. TGL. NTPN. NILAI;

d. Metode-4 dengan elemen kunci NTB/NTP AKUN. NILAI;

e. Metode-5 dengan elemen kunci NTPN. NILAI;

f. Metode-6 dengan elemen kunci TGL. NTPN. AKUN. NILAI;

g. Metode-7 dengan elemen kunci BULAN NTPN. AKUN. NILAI;

h. Metode-8 dengan elemen kunci NTPN. 
AKRUAL: Jurnal Akuntansi, volume 9, nomor 1, Oktober 2017, (20-40)

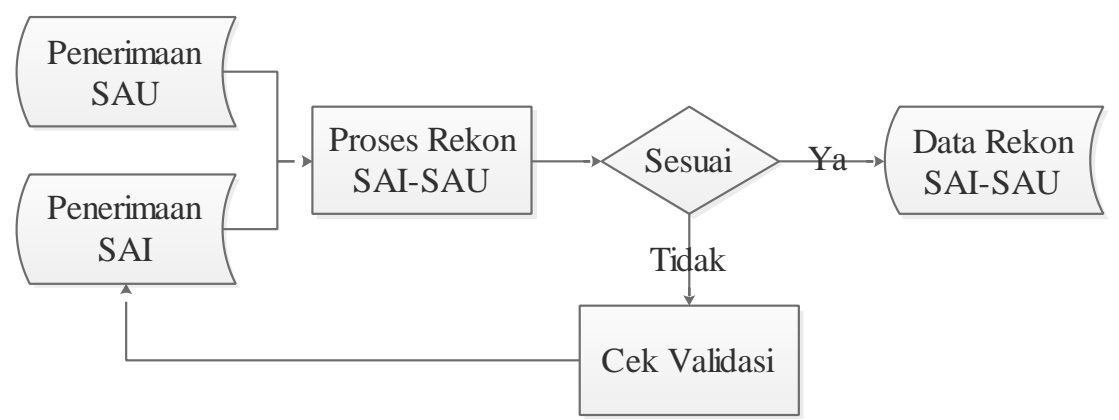

Gambar 8. Proses Rekonsiliasi Penerimaan Tingkat Eselon I DJBC

Data unmatch dilakukan pengecekan

kembali oleh satker mengenai kebenaran data yang tercatat pada SAI. Setelah dilakukan

\section{Pengendalian Ideal}

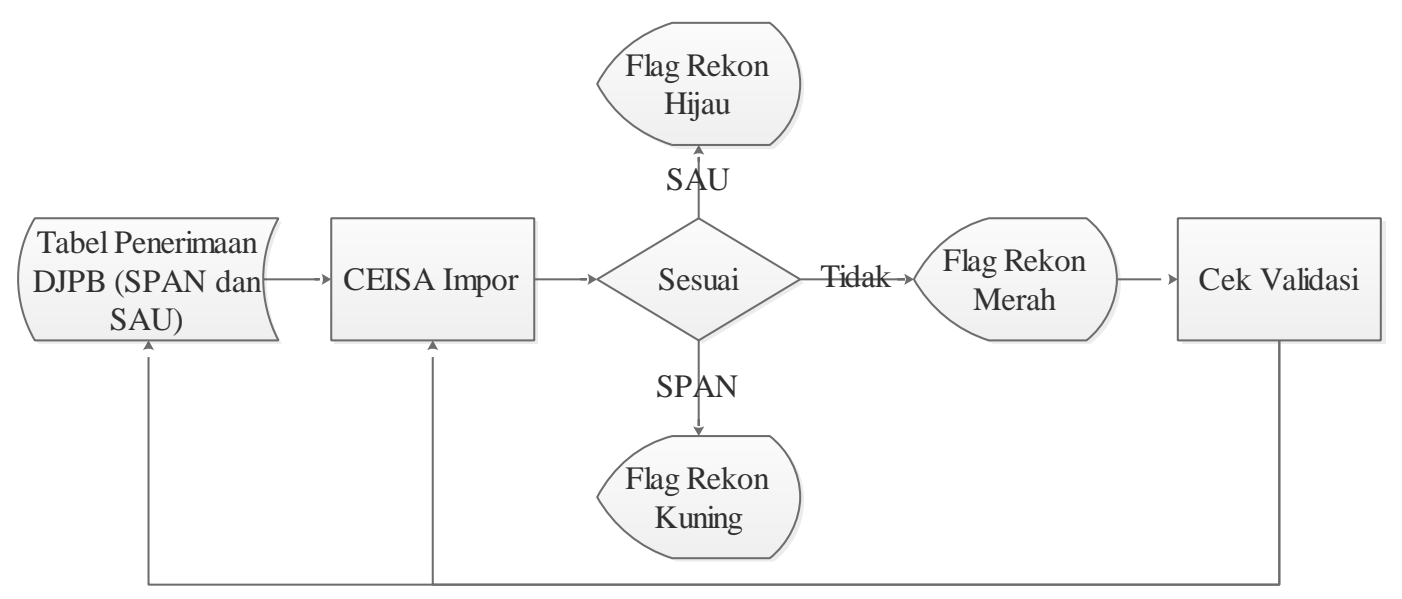

Gambar 9. Proses Rekonsiliasi Penerimaan Tingkat Eselon I DJBC

Rekonsilasi penerimaan pun bukanlah suatu kegiatan khusus yang harus mengunduh dari aplikasi, mengisi kertas kerja penerimaan, lalu dilakukan rekonsiliasi dengan SAU. Namun rekonsiliasi terjadi secara sistem. Sehingga data yang diunduh dari sistem merupakan data yang sudah terekonsiliasi.

Tabel penerimaan DJPB (SPAN dan SAU) dihubungkan dengan menggunakan file kirim secara langsung ke database CEISA. Dengan demikian, setiap transaksi yang tercantum, langsung tersedia notifikasi untuk mengetahui validitas penerimaan tersebut. validasi, maka proses rekonsiliasi diulangi kembali.

\section{Pengendalian Antara}

Pengendalian output dilakukan dengan membandingkan antara data penerimaan satker dan data SAU. Apabila data SAU belum sepenuhnya tersedia untuk satu periode, maka dapat digunakan data SPAN. Dengan demikian proses rekonsiliasi dilakukan berjenjang. Hal ini untuk memudahkan proses verifikasi atas data yang dinyatakan SAI unmatch maupun SAU unmatch. 
Arif,Daniel, Disharmoni Sistem Informasi Akuntansi Penerimaan Dan Piutang...

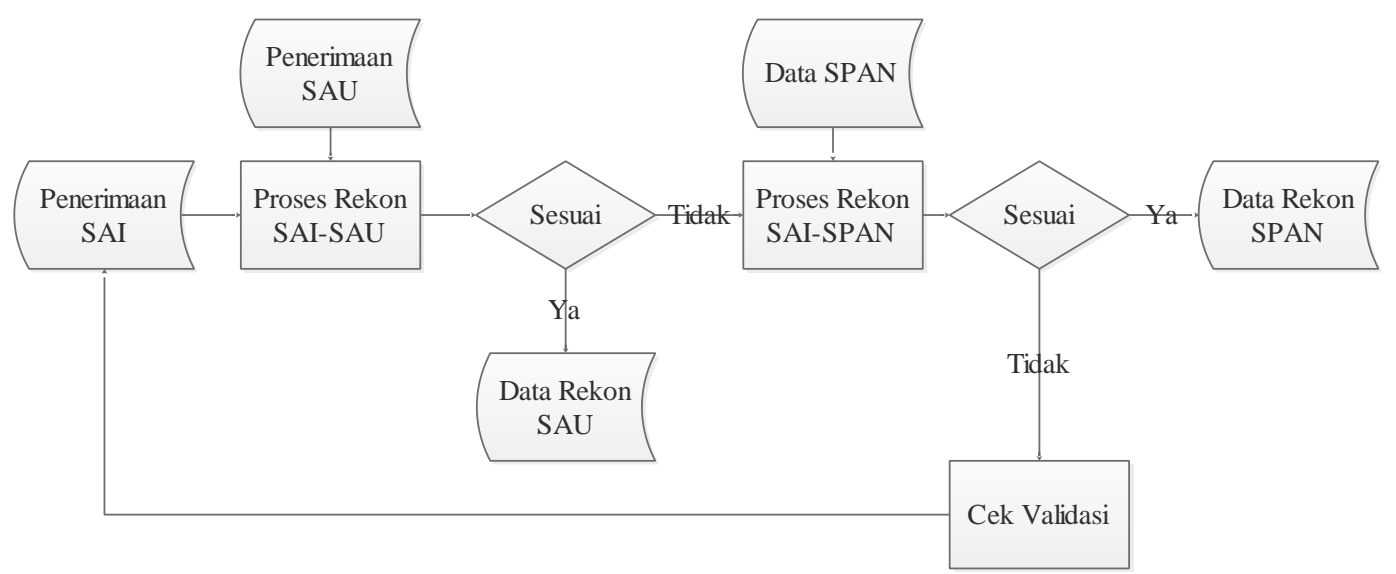

Gambar 10. Pengendalian Output

\section{Pengendalian Input Piutang}

\section{Kondisi Saat Ini}

Pengendalian input pada SAPP dilakukan dengan otorisasi oleh pejabat perbendaharaan. Mutasi tambah piutang dilakukan oleh penerbit piutang dan penatausaha piutang. Di sisi lain, mutasi kurang piutang yang dilakukan secara manual dengan perekaman ke dalam SAPP harus dengan otorisasi Kepala Seksi Perbendaharaan atau Penagihan. Mutasi kurang piutang manual ini bisa disebabkan karena adanya pembuatan kode billing yang dilakukan sendiri oleh importir, sehingga tidak berhasil terekonsiliasi dengan tagihan di SAPP. Selain itu, mutasi kurang juga akibat pembatalan surat teguran karena ternyata piutang awal telah dilunasi.

Mulai tahun 2014, penggunaan SAPP sebagai data sumber piutang digunakan dalam penyusunan laporan keuangan. Dengan demikian, seluruh data piutang harus tercatat dalam SAPP. Selain digunakan dalam penatausahaan piutang, SAPP juga digunakan sebagai sumber data untuk menentukan status pemblokiran kegiatan kepabeanan. Data yang diambil adalah data yang masih memiliki flag rekon merah (Gambar 10). Apabila status SAPP masih merah (belum lunas) sampai dengan batas waktu yang ditentukan, maka importir tersebut tidak dapat melaksanakan kegiatan kepabeanan.

Permasalahannya, penerbitan dokumen penetapan yang menjadi piutang tidak dilakukan melalui SAPP. Dengan demikian, terjadi adanya time lag antara penerbitan dokumen piutang dengan perekaman dalam SAPP. Hal ini juga dikhawatirkan adanya risiko piutang tersebut tidak tercantum dalam SAPP.

Permasalahan lainnya adalah adanya rincian data piutang terbit sebelum tahun 2012 yang tidak masuk dalam SAPP, yang tercantum hanyalah rekapitulasi data saja. Mungkin secara laporan keuangan tidak menjadi masalah. Namun, dengan tidak tercantumnya rincian data piutang, mekanisme pemblokiran tidak dapat dilakukan secara sistem. Sehingga perusahaan atau importir yang belum melakukan pelunasan tagihan, masih dapat melakukan kegiatan kepabeanan. 
AKRUAL: Jurnal Akuntansi, volume 9, nomor 1, Oktober 2017, (20-40)

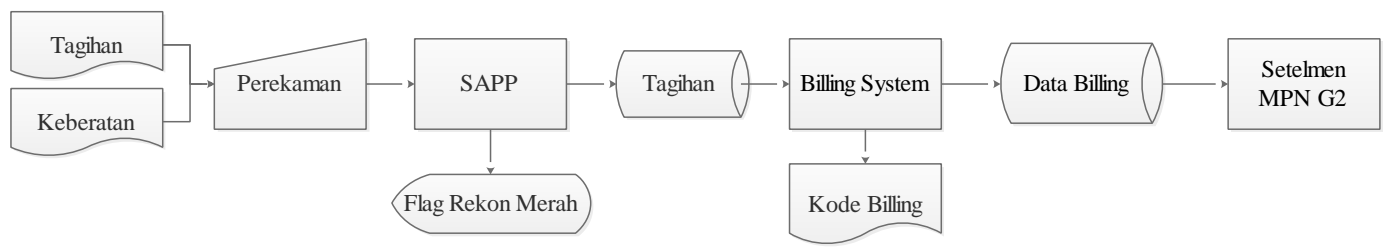

Gambar 11. Proses Pembuatan Kode Billing dari SAPP

Kode billing terbit setelah dilakukan perekaman dokumen piutang dalam SAPP (Gambar 11). Selanjutnya apabila dilakukan pelunasan, maka notifikasi pada SAPP berubah dari sebelumnya flag merah, menjadi flag hijau. Perubahan ini secara otomatis dilakukan setelah SAPP menerima data NTPN yang diteruskan dari Setelmen MPN G2 ke billing sistem.

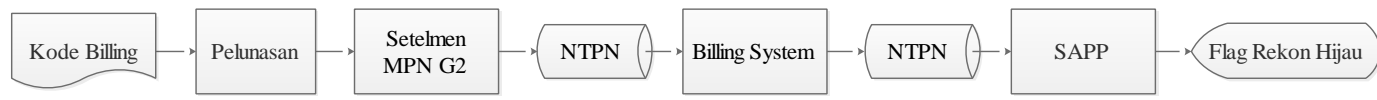

Gambar 12. Pelaporan Pelunasan tanpa kode billing

Apabila importir melakukan pelunasan tidak dengan kode billing yang dibuat oleh DJBC, dengan kata lain membuat sendiri billing manual, maka data pelunasan tersebut tidak secara otomatis masuk ke dalam SAPP. Dengan demikian status flag di SAPP masih merah meskipun piutang tersebut telah dilunasi. Jika importir tidak pro aktif melaporkan pelunasan tersebut, maka akan terjadi piutang overstated. Selain itu, importir tersebut juga akan terkena pemblokiran secara sistem. Biasanya setelah mengetahui dirinya terkena pemblokiran, importir tersebut akan melapor ke kantor pelayanan DJBC atas pelunasan tagihan (Gambar 12).

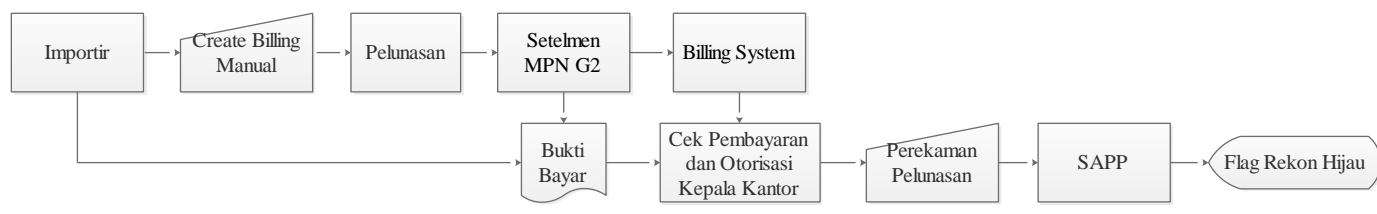

Gambar 13. Pelaporan Pelunasan Billing Manual

Permasalahan lainnya adalah belum ada informasi putusan banding yang terotomasi dari Pengadilan Pajak. Pada saat penelitian dilakukan, masih diupayakan adanya mekanisme pertukaran data dari Sekretariat Pengadilan Pajak kepada DJBC. Informasi putusan banding ini penting sebagai data sumber apakah piutang tersebut bertambah atau tidak.

\section{Pengendalian Ideal}

Proses penerbitan dokumen piutang yang tidak tersistem dapat berisiko terjadi kesalahan. Hal yang perlu dibenahi adalah segala dokumen piutang harus terbit melalui SAPP (Gambar 13). Proses pembatalan penetapan dokumen pun juga harus melalui sistem. Dengan demikian, pengendalian input piutang dapat dibenahi. 
Arif,Daniel, Disharmoni Sistem Informasi Akuntansi Penerimaan Dan Piutang...

Terkait dengan informasi putusan banding dari Pengadilan Pajak yang dikirim melalui mekanisme pertukaran data, harus dibuat adanya jembatan penghubung antara data pooling dengan SAPP. Sehingga secara otomatis apabila telah terbit putusan banding, misalnya dengan putusan tolak naik, dapat masuk dalam SAPP sebagai mutasi tambah piutang.

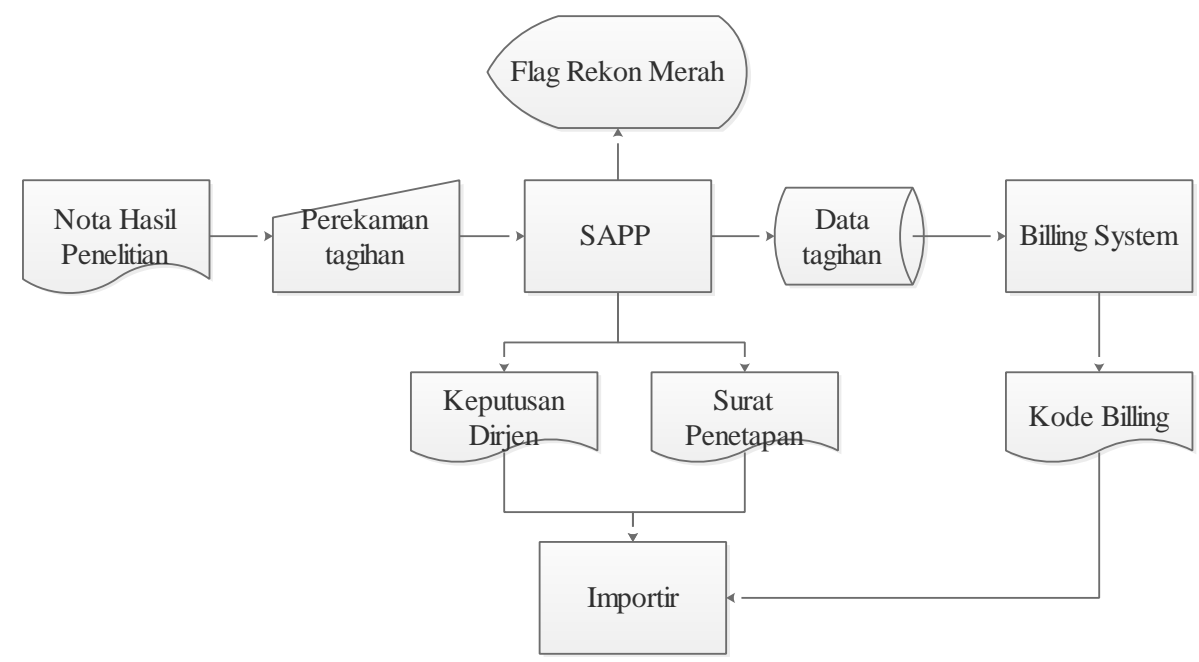

Gambar 14. Penerbitan Dokumen Piutang

\section{Pengendalian Antara}

Sebelum seluruh dokumen penetapan piutang diterbitkan melalui SAPP, yang perlu dijaga adalah mekanisme penomoran dokumen piutang harus melalui SAPP. Hal ini untuk menghindari adanya time lag perekaman piutang. Selain itu, secara proses bisnis menjaga agar pelaku usaha atau importir mendapatkan kode billing secara sistem. Apabila importir tidak melunasi tagihan sesuai dengan ketentuan, CEISA secara otomatis akan melakkan pemblokiran.

Piutang yang terbit sebelum tahun 2012 harus direkonsiliasi kembali dengan data keberatan dan informasi putusan banding dari Pengadilan Pajak. Setelah dibersihkan, maka daftar piutang tersebut dapat dimasukkan dalam SAPP.

\section{Pengendalian Proses Piutang}

\section{Kondisi Saat Ini}

Pengendalian proses terkait piutang dilakukan dengan menggunakan kertas kerja piutang dalam format excel. Sama halnya dengan penerimaan, pengendalian proses pada piutang dilakukan dengan menggunakan Berita Acara Rekonsiliasi. Sayangnya, Tim DJBC Pusat tidak memiliki data pembanding atas laporan piutang yang disajikan oleh kantor pelayanan. Sehingga dikhawatirkan adanya piutang yang belum tercatat ataupun masih tercatat walau sudah dilunasi.

\section{Pengendalian Ideal}

Ketika seluruh data diolah di SAPP, maka secara otomatis data piutang sudah tersedia. Pengendalian proses dilakukan dengan membandingkan secara batch antara data di tingkat satker dan data di tingkat pusat. Pengendalian proses dengan pihak luar dilakukan secara periodik dengan 
AKRUAL: Jurnal Akuntansi, volume 9, nomor 1, Oktober 2017, (20-40)

membandingkan data putusan banding dengan data piutang di SAPP. Selain itu, mutasi kurang piutang dari pelunasan seharusnya sama dengan penerimaan dengan dokumen dasar piutang. Dengan demikian, secara komprehensif validitas piutang lebih terjaga.

\section{Pengendalian Antara}

Sebelum seluruh data diolah di SAPP, maka yang harus dijaga dari piutang adalah mutasi atau pergerakannya. Validasi mutasi piutang terbit dapat dilakukan dengan menggabungkan seluruh data dokumen piutang terbit yang berasal dari surat penetapan, putusan keberatan, putusan banding, dan surat teguran/paksa. Selanjutnya dilakukan rekapitulasi secara batch piutang terbit. Apabila data hasil proses penggabungan tersebut sesuai dengan data di SAPP, maka angka mutasi piutang terbit telah tervalidasi. Jika tidak, maka dilakukan pengecekan kembali apakah kurang input di SAPP atau data dokumen piutang belum dihimpun. Gambar proses validasi piutang terbit tercantum pada Gambar

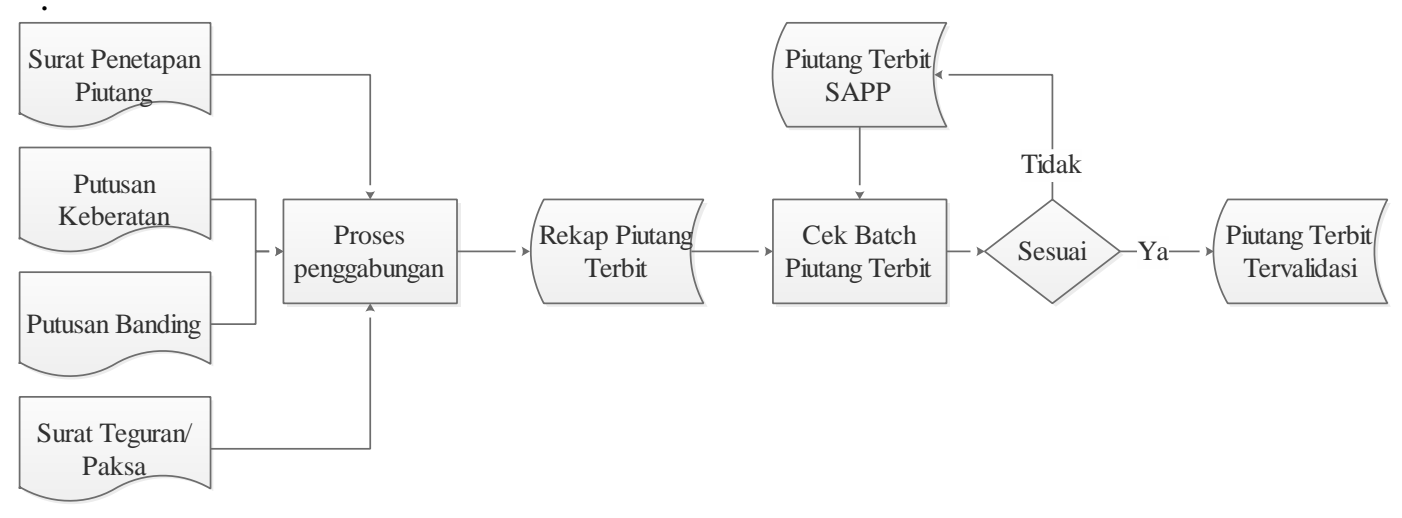

Gambar 15. Validasi Mutasi Tambah Piutang

Sama halnya dengan mutasi tambah, validasi mutasi kurang piutang juga dilakukan dengan menggabungkan data pelunasan, putusan keberatan, putusan banding, pembatalan, dan SP3DRI. Selanjutnya dilakukan rekapitulasi secara batch piutang kurang. Apabila data hasil proses

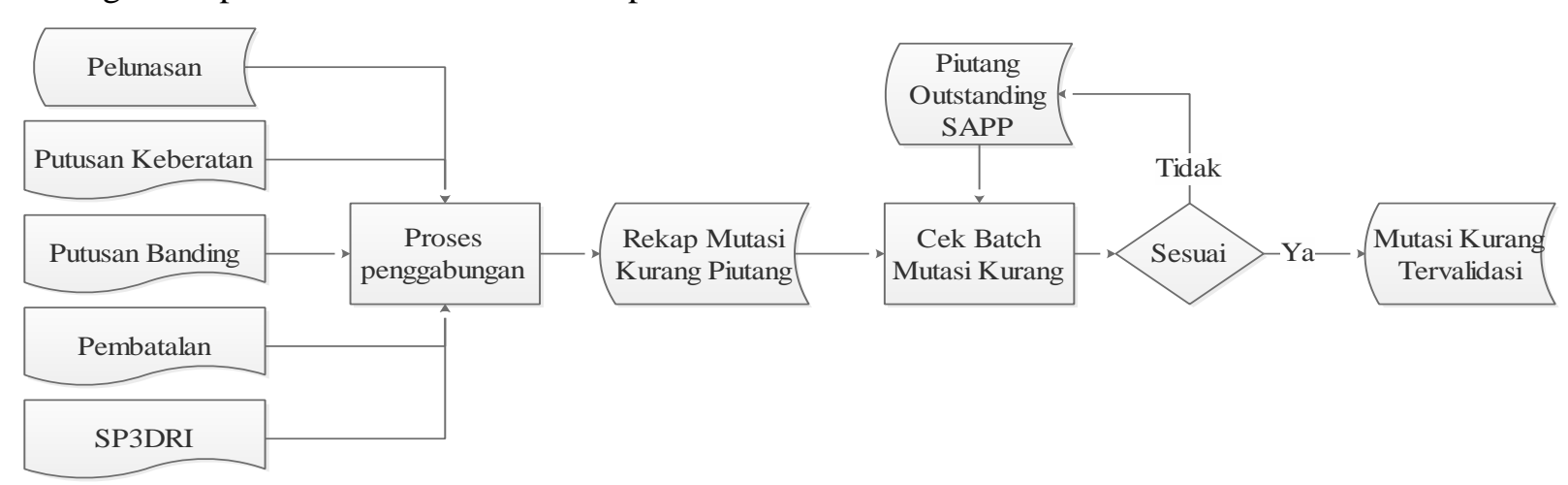

Gambar 16. Validasi Mutasi Kurang Piutang

penggabungan tersebut sesuai dengan data di SAPP, maka angka mutasi piutang kurang telah tervalidasi. Jika tidak, maka dilakukan pengecekan kembali apakah terdapat pelunasan manual, atau adanya kesalahan data. Gambar proses validasi piutang kurang tercantum pada Gambar 15. 
Arif,Daniel, Disharmoni Sistem Informasi Akuntansi Penerimaan Dan Piutang...

Pengendalian Output Piutang

\section{Kondisi Saat Ini}

Pengendalian output piutang dilakukan pada saat rekonsiliasi. Secara umum, proses pengendalian input tersaji pada Gambar 16. Data piutang dari SAPP diunduh baik yang sudah dilunasi secara sistem (billing) maupun yang dilakukan pelunasan secara manual. Hasil dari kedua data tersebut dipadukan dengan menghilangkan data piutang yang sama untuk menghindari adanya duplikasi. Hasil dari unduhan SAPP kemudian diolah menjadi kertas kerja piutang.

Untuk memvalidasi data piutang, penatausaha piutang pada kantor pelayanan menunggu sampai batas akhir penyampaian laporan piutang untuk memitigasi adanya piutang yang baru diinput di SAPP. Informasi putusan banding dari Pengadilan Pajak pada saat penelitian masih diusahakan tersedia melalui mekanisme pertukaran data.

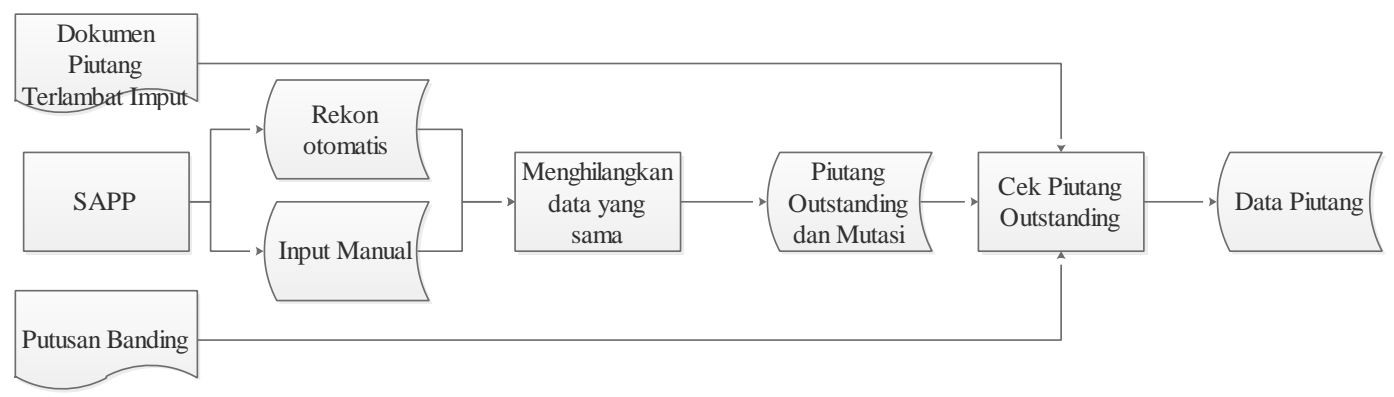

Gambar 17. Pengendalian Output Piutang

\section{Pengendalian Ideal}

Sebagai bentuk transparansi tagihan negara, data piutang pada SAPP sebaiknya dapat diketahui secara jelas oleh pihak yang memiliki hutang. Misalnya di Ditjen pajak sedang dibuat tax account payer. Jadi setiap wajib pajak nantinya dapat mengetahui berapa hutangnya, berapa lebih bayarnya. Pada saat pembayaran pun wajib pajak mengetahui apa yang akan dibayar, seperti kita membayar tagihan melalui perbankan.

\section{Pengendalian Antara}

Sebelum SAPP berjalan murni, maka yang perlu diperkuat adalah output dari SAPP. Hal ini penting untuk mempermudah penyusunan laporan dan monitoring penyelesaian piutang. Penyampaian laporan piutang secara manual dapat dihilangkan apabila SAPP dapat mengakomodir data piutang secara lengkap dan mutakhir.

\section{KESIMPULAN}

Secara umum, sistem informasi akuntansi penerimaan dan piutang DJBC masih belum selaras dengan proses bisnis yang dijalankan. Masih terlihat adanya gap antara akuntansi dengan proses bisnis, sebagai contoh sistem komputerisasi pelayanan tidak dapat dijadikan sebagai sumber data penerimaan. Padahal seharusnya akuntansi bukanlah suatu upaya atau beban tersendiri. Selain itu, manfaat dari informasi yang dihasilkan dapat memberikan nilai tambah bagi perbaikan proses bisnis.

Titik kritis pengendalian penerimaan berada di rekonsiliasi yang tidak tersistem. Seharusnya data validasi SAU terhubung 
dengan CEISA yang dapat menginformasikan status transaksi tersebut melalui suatu notifikasi.

Terkait piutang, titik kritis pengendalian berada pada masih harus adanya sentuhan manual dalam penatausahaan piutang, baik input maupun pelaporannya. SAPP lebih banyak berfungsi sebagai proses bisnis. Di sisi lain, untuk menyusun laporan keuangan, SAPP belum bisa diandalkan penuh dalam menyajikan angka piutang yang valid. Hal ini disebabkan belum terkoneksinya SAPP dengan pertukaran data dan penerbitan dokumen piutang belum dilakukan secara sistem.

\section{Implikasi Penelitian}

Implikasi penelitian ini adalah perlunya perbaikan pada proses bisnis CEISA agar tidak hanya menjadi sistem pelayanan saja, melainkan terhubung dengan sistem penerimaan. Sehingga proses pelayanan kegiatan kepabeanan lebih pasti dan aman dalam hal menjaga penerimaan negara tanpa mengorbankan pelayanan kepada pengguna jasa. Adanya risiko bawaan piutang membuat DJBC harus lebih prudent menjaga penatausahaan piutang melalui perbaikan mekanisme kerja SAPP dan menjaga alur sistem tetap berjalan dengan baik.

\section{Keterbatasan Penelitian dan Arah Bagi Penelitian Selanjutnya}

Penelitian ini terbatas hanya pada kegiatan kepabeanan impor barang untuk digunakan. Penelitian belum mencakup penerimaan dan piutang pada kegiatan fasilitas kepabeanan, impor sementara, cukai, dan sebagainya. Dengan demikian, penelitian berikutnya dapat lebih mengeksplor pengendalian penerimaan dan piutang pada kegiatan kepabeanan dan cukai yang lainnya.

\section{DAFTAR PUSTAKA}

Abdallah, J., \& Adel, A. 2013. The Impact of Using Accounting Information Systems on The Quality of Financial Statements Submitted to The Income and Sales Tax Department in Jordan. European Scientific Journal. Terdapat pada:https://eujournal.org/index.php/es $\mathrm{j} /$ article/view/2264

Ada, Ş., \& Ghaffarzadeh, M. 2015. Decision Making Based on Management Information System and Decision Support System. Journal for Studies in Management and Planning, 1(3), 206217.https://doi.org/10.13187/er.2015.93 .260

Bell, T. B., Knechel, W. R., Payne, J. L., \& Willingham, J. J. 1998. An Empirical Investigation of the Relationship Between the Computerization of Accounting Systems and the Incidence and Size of Audit Differences. Auditing: A Journal of Practice \& Theory, 17(1), 13-38.

Bisbal, J., Lawless, D., Wu, B., \& Grimson, J. 1999. Legacy Information Systems: Issues and Directions. IEEE software, 16(5), 103. terdapat pada: http://ieeexplore.ieee.org/document/79 5108/

Burks, J. J. 2015. Accounting Errors in Nonprofit Organizations. Accounting Horizons, 29(2), 341-361. DOI: https://doi.org/10.2308/acch-51017

Cong, Y., \& Romero, J. 2013. On Information Systems Complexity and Vulnerability. Journal of Information Systems, $\quad 27(2), \quad 51$. https://doi.org/10.2308/isys-50562

Cram, W. A., \& Gallupe, R. B. 2016. A Method to Evaluate Information Systems Control Alignment. Journal of Information Systems, 30(1), 117$135 . \quad$ https://doi.org/10.2308/isys51297

Elliott, R. K. 1992. The Third Wave Breaks on The Shores of Accounting. Accounting Horizons, 6(2), 61. 
Florin-Constantin, D. (2013). The Users of Accounting Information and Their Needs, Timisoara.

Ghasemi, M., Shafeiepour, V., Aslani, M., \& Barvayeh, E. 2011. The Impact of Information Technology (IT) on Modern Accounting Systems. Procedia - Social and Behavioral Sciences, $\quad 28, \quad 112-116$. https://doi.org/10.1016/j.sbspro.2011.1 1.023

Gheorghe, D. 2012. The Accounting Information Quality Concept. Economics, Management and Financial Markets, 7(4), 326-336.

Terdapat pada: http://econpapers.repec.org

Granlund, M. 2011. Extending AIS Research to Management Accounting and Control Issues: A Research Note. International Journal of Accounting Information Systems, 12(1), 3-19. DOI:

https://doi.org/10.1016/j.accinf.2010.1 1.001

Grant, G. H., Miller, K. C., \& Alali, F. 2008. The Effect of IT Controls on Financial Reporting. Managerial Auditing Journal, 23(8), 803-823.

DOI:

https://doi.org/10.1108/026869008108 99536

Huang, S.-M., Yen, D. C., Hung, Y.-C., Zhou, Y.-J., \& Hua, J.-S. 2009. A Business Process Gap Detecting Mechanism Between Information System Process Flow and Internal Control Flow. Decision Support Systems, 47(4), 436454. DOI:

https://doi.org/10.1016/j.dss.2009.04.0 $\underline{11}$

Lim, F. P. C. 2013. Impact of Information Technology on Accounting Systems. Asia-Pasific Jornal of Multimedia Services Convergent with Art, Humanities and Socialgy, 3(2), 93106.

DOI:https://doi.org/10.14257/ajmscahs .2013 .12 .02

Maharsi, S. 2000. Pengaruh Perkembangan Teknologi Informasi Terhadap Bidang Akuntansi Manajemen. Jurnal Akuntansi \& Keuangan, 2(2), 127-137. Terdapat pada: http://puslit.petra.ac.id/journals/accoun ting/

Moorthy, M. K., Voon, O. O., Samsuri, C. A. S. B., Gopalan, M., \& Yew, K.-T. 2012. Application of Information Technology in Management Accounting Decision Making. International Journal of Academic Research in Business and Social Sciences, 2(3), 1. Terdapat pada: hrmars.com/index.php/pages/detail/IJA RBSS

Newcomer, K. E., \& Caudle, S. L. 1991. Evaluating Public Sector Information Systems: More Than Meets the Eye. Public Administration Review, 51(5), 377-384.

DOI:https://doi.org/10.2307/976406

O'Donnell, E., \& David, J. S. 2000. How Information Systems Influence User Decisions: A Research Framework and Literature Review. International Journal of Accounting Information Systems, 1(3), 178-203. https://doi.org/10.1016/s14670895(00)00009-9

Patasiene, I., Zaukas, G., \& Patasius, M. 2015. Integration of Business Game for Improving Literacy of Accounting Information Systems. Procedia Social and Behavioral Sciences, 213, 304-308.

https://doi.org/10.1016/j.sbspro.2015.1 1.542

Peraturan Menteri Keuangan. (2015). Peraturan Menteri Keuangan Nomor 234/PMK.01/2015 tentang Organisasi dan Tata Kerja Kementerian Keuangan.

Terdapat pada: www.jdih.kemenkeu.go.id

Ramli, I., \& Iskandar, D. 2014. Control Authority, Business Strategy, and the Characteristics of Management Accounting Information Systems. Procedia - Social and Behavioral Sciences, $\quad 164, \quad 384-390$. https://doi.org/10.1016/j.sbspro.2014.1 1.092 
AKRUAL: Jurnal Akuntansi, volume 9, nomor 1, Oktober 2017, (20-40)

Sonnenberg, C., \& Jan vom, B. 2014. The Missing Link Between BPM and Accounting. Business Process Management Journal, 20(2), 213-246. https://doi.org/10.1108/bpmj-12-2012$\underline{0136}$
Sugiyono. 2016. Memahami Penelitian Kualitatif. Bandung: Alfabeta.

Surendro, K. 2007. Pemanfaatan Enterprise Architecture Planning untuk Perencanaan Strategis Sistem Informasi. Jurnal Informatika, 8(1), 19. Terdapat pada: jurnalinformatika.petra.ac.id 